\title{
Gerontological Nursing
}

National Cancer Institute

\section{Source}

National Cancer Institute. Gerontological Nursing. NCI Thesaurus. Code C18813.

Nursing practices for older age individuals 